\title{
Chemical and cytotoxic analyses of three varieties of Brazilian propolis (green propolis, jataí propolis and brown propolis) and its anti-Sporothrix brasiliensis in vitro activity
}

[Análises químicas e citotóxicas de três variedades de própolis brasileiras (própolis verde, própolis jatai e própolis marrom) e sua atividade in vitro anti-Sporothrix brasiliensis]

\author{
C.M. Peter ${ }^{1}$, S.B. Waller ${ }^{1}$, T. Picoli ${ }^{1}$, L.G. Osório ${ }^{1}$, J.L. Zani ${ }^{1}$, M.C.A. Meireles ${ }^{1}$, \\ R.O. Faria ${ }^{1}$, J.R.B. Mello ${ }^{2}$, S.O. Hubner ${ }^{1}$, M. Lima ${ }^{1}$, G. Fischer ${ }^{1}$ \\ ${ }^{1}$ Universidade Federal de Pelotas - Pelotas, RS \\ ${ }^{2}$ Universidade Federal do Rio Grande do Sul - Porto Alegre, RS
}

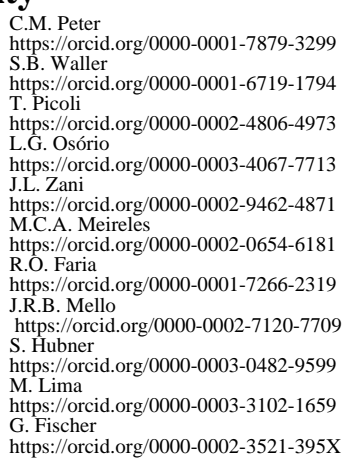

\begin{abstract}
\end{abstract}
In this study, we described the antifungal activity of three Brazilian propolis extracts: brown, green and from jataí bees against Sporothrix brasiliensis. The extracts were obtained from ethanolic extraction and their chemical composition was determined by high-performance liquid chromatography coupled to mass spectrometry. The cellular toxicity was measured in MDBK (Madin-Darby Bovine Kidney) cells and quantified by the MTT assay (3- (4,5 dimethylthiazol-2yl -2,5-diphenyl-2H bromine tetrazolato). For antifungal activity, the minimum inhibitory concentration (MIC) and minimum fungicidal concentration (MFC) were determined by broth microdilution. The results showed that cell toxicity was not observed at lower concentrations $(0.097$ to $0.39 \mu \mathrm{g} / \mathrm{ml})$ for all extracts in comparison to cell control. Among the chemical compounds identified, caffeic acid, p-coumaric acid, chlorogenic acid, ferulic acid and rutin were quantified. In antifungal activity, green and jataí did not exhibit activity against the isolates (MIC and MFC greater than $0.78 \mathrm{mg} / \mathrm{ml}$ ). However, all isolates of $S$. brasiliensis were sensitive to brown propolis (MIC of 0.09 to $0.78 \mathrm{mg} / \mathrm{ml}$ ), including the standard strain $(\mathrm{P}<0.001)$. Among the Brazilian propolis studied, the brown propolis showed activity against the $S$. brasiliensis isolates and more studies should be undertaken in order to evaluate its promising use in the treatment of sporotrichosis.

Keywords: zoonosis, itraconazole, antifungal resistance, therapeutic alternative

\section{RESUMO}

Neste estudo, descreveu-se a atividade antifúngica de três extratos de própolis brasileiras: marrom, verde e de abelhas jataí (Tetragonisca angustula), contra Sporothrix brasiliensis. Os extratos foram obtidos de extração etanólica, e a sua composição química foi determinada por cromatografia líquida de alta eficiência, acoplada à espectrometria de massa. A toxicidade celular foi medida em células MDBK (Madin-Darby Bovine Kidney), avaliada por observação microscópica e quantificada pelo ensaio MTT (3- (4,5-dimetiltiazol-2-ilo -2,5-difenil-2H bromo tetrazolato). Para a atividade antifúngica, determinouse a concentração inibitória mínima (CIM) e a concentração fungicida mínima (CFM) por meio de microdiluição em caldo. Os resultados mostraram que a toxicidade celular não foi observada em concentrações menores $(0,097$ a $0,39 \mu \mathrm{g} / \mathrm{ml})$. Entre os compostos químicos identificados, foram quantificados o ácido cafeico, ácido p-cumárico, ácido clorogênico, ácido ferúlico e a rutina. Na atividade antifúngica, as própolis verde e jataí não apresentaram atividade contra os isolados (CIM e CFM maior que $0,78 \mathrm{mg} / \mathrm{ml}$ ), porém todos os isolados de $\mathrm{S}$. brasiliensis foram sensíveis à própolis marrom (CIM de 0,09 a 0,78mg/ml), incluindo a cepa padrão $(P<0,001)$. Entre as própolis brasileiras estudadas, a marrom mostrou atividade contra $\mathrm{S}$. brasiliensis, e mais estudos devem ser realizados para avaliar seu uso promissor no tratamento da esporotricose.

Palavras-chave: zoonoses, itraconazol, resistência antifúngica, alternativa terapêutica

Recebido em 3 de julho de 2017

Aceito em 4 de abril de 2018

E-mail: cristina_peter@hotmail.com 


\section{INTRODUCTION}

Among the infectious diseases of public health importance, sporotrichosis is one of the emerging fungal infections occurring in several countries, mainly in India, Mexico, Colombia, Peru, Brazil, South Africa and Japan (Carrada-Bravo e Olvera-Macías et al., 2013). The disease is characterized by nodular and ulcerative lesions limited to the subcutaneous tissue and may also involve the lymphatic system, as well as spreading to internal organs in a systemic form in severe forms of the disease, occurring especially in immunocompromised patients (Madrid et al., 2012; Paixão et al., 2015).

The transmission occurs through traumatic inoculation of conidia in skin tissue and may occur through the bites and scratches of sick cats (Romeo and Criseo, 2013). Pathogenic species of the Sporothrix schenckii complex (Marimon et al., 2008) may provoke the disease, with Sporothrix brasiliensis being considered the most virulent species and with high prevalence in feline sporotrichosis outbreaks in Brazil (Chaves et al., 2013; Rodrigues et al., 2014). Several therapeutic protocols are recommended, and itraconazole is considered the antifungal of choice. However, the emergence of antifungal resistance has been reported in recent years (Marimon et al., 2008; Chaves et al., 2013; Stopiglia et al., 2014; Waller et al., 2015) which alerted researchers to the need to search for new antifungal compounds.

It is known that the use of plant extracts is one of the oldest practices of humanity and the use of traditional medicine is essential in basic health primary care in developing countries (Yigit et al., 2009). Bee products such as honey, royal jelly, pollen, propolis, among others have been increasingly used in human and veterinary medicine as natural products (Bastos et al., 2011). Individually, propolis stands out for its therapeutic properties, such as antimicrobial, anti-inflammatory, healing, anesthetic, and anticariogenic properties, in addition to be used in the pharmaceutical and food industries (Ortega et al., 2011).

Resinous material from the collection of exudates and plant buds by bees, along with their produced enzymes and waxes (Bankova et al., 2000), the propolis (from the Greek pro: "in defense" and polis: "city") has great importance for bees since it prevents the entry of intruders into the hive and embalms dead bodies in order to avoid decomposition and the spread of odors (Simone-finstrom and Spivak, 2012). Among the present compounds, flavonoids are important for their anti-inflammatory and antimicrobial activities (Sonmez et al., 2005) including against pathogenic fungi (Siqueira et al., 2009).

Among the species of medical importance, Candida albicans, C. krusei, C. glabrata, $C$. tropicalis, Cryptococcus neoformans, Malassezia pachydermatis, Paracoccidioides brasiliensis, Microsporum gypseum, Trichophyton rubrum, $T$. mentagrophytes and $T$. verrucusom already have proven sensitive to propolis produced by different bees throughout the world, including Brazil (Siqueira et al., 2009) Argentina (Agüero et al., 2014), United States (Chua et al., 2014), Croatia (Jug et al., 2014), Turkey (Çam et al., 2009) and Iran (Khosravi et al., 2013). The promising antimicrobial activity of propolis was also observed in fungi resistant to conventional drugs.

In sporotrichosis, antifungal resistance has been increasingly observed, including to itraconazole (Marimon et al., 2008; Stopiglia et al., 2014; Waller et al., 2015), making therapeutic success difficult in human and animal cases. Although there are few studies regarding the control of sporotrichosis through natural products, $S$. schenckii has been sensitive to Brazilian Bulgarian propolis (Salomão et al., 2008) however, there are no studies against $S$. brasiliensis, which is considered the most prevalent species in feline sporotrichosis in Brazil (Sanchonete et al., 2015; Waller et al., 2015). Due to the need to search for new antifungal compounds in the treatment of sporotrichosis, this work aimed to evaluate the anti-Sporothrix brasiliensis activity of three propolis varieties produced in Brazil by different bees, and analyze their chemical composition and cytotoxic effects.

\section{MATERIALS AND METHODS}

Samples of brown propolis were commercially purchased from Cooperativa de Apicultores $e$ Fruticultores da Região Sul (Beekeeper and Fruit Grower Cooperative of the Southern Region), located in the city of Pelotas/ RS, Brazil; green 
propolis was acquired from a commercial company (Nectar Farmacêutica ${ }^{\circledR}$ LTDA, Siderópolis/SC, Brazil), whereas propolis from jatai bees was obtained from an apiary of stingless bees located in the city of Morro Redondo/RS, Brazil.

The hydroalcoholic extracts were prepared as described by Paulino et al. (2002). The propolis samples were frozen at $-70^{\circ} \mathrm{C}$ and, then were ground. The extraction was performed in a solution containing alcohol $96^{\circ} \mathrm{GL}$ in a ratio of 1:3 to propolis alcohol under stirring for 24 hours at $37^{\circ} \mathrm{C}$. Subsequently, the solvent was evaporated and the resulting dry matter was dissolved in phosphate buffer $(\mathrm{pH}$ 7.2) and

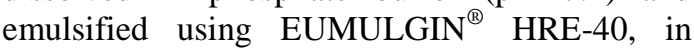
order to obtain the final concentration of $100 \mathrm{mg} / \mathrm{ml}$. Sterilization of the compound was conducted in hydrophilic filter with porosity of $22 \mu \mathrm{m}$. Afterwards, the dilution was performed with sterile distilled water until achieving the concentration of use.

The chemical composition of propolis extracts was determined by liquid chromatography coupled to mass spectrometry. For this, $10 \mu \mathrm{l}$ of the extracts were injected into a liquid chromatograph of ultra high efficiency (Shimadzu Prominence) coupled to mass spectroscopy of high resolution mass (quadrupole-time of flight type) (micrOTOF -Q, Bruker Daltonics). Phenolic compounds were separated using C18 pre-column $(2.0 \times 4 \mathrm{~mm})$ and C18 Luna column $(2.0 \times 150 \mathrm{~mm}, 100 \AA$, $3 \mathrm{mM}$ ) Phenomenex (Torrance, CA, USA), being formic acid solution in water $(0.1 \% \mathrm{v} / \mathrm{v}$, eluent A) and methanol (eluent B) used as mobile phase at a flow rate of $0.2 \mathrm{ml} / \mathrm{min}$ and the column temperature at $40^{\circ} \mathrm{C}$. The elution gradient was: 0-2min, $10 \% \mathrm{~B} ; 2-15 \mathrm{~min}, 10-75 \% \mathrm{~B} ; 15-30 \mathrm{~min}$, $75 \% \mathrm{~B} ; 30-32 \mathrm{~min} 75-10 \% \mathrm{~B} ; 32-40 \mathrm{~min}, 10 \% \mathrm{~B}$. The PDA detector was defined to scan in the range of $210-800 \mathrm{~nm}$. The mass spectrometer was operated in the negative ESI mode, with a voltage of the capillary in $4000 \mathrm{~V}$, nebulization gas pressure $\left(\mathrm{N}_{2}\right)$ of 2 bar, drying gas at $8 \mathrm{~L} / \mathrm{min}$ and source temperature of $180^{\circ} \mathrm{C}$ using the equipment default parameters. The equipment was calibrated with $10 \mathrm{mM}$ sodium formate, covering the entire range of acquisition $(\mathrm{m} / \mathrm{z}$ of 50 to 1200$)$. The mass spectrum was processed using the Data Analysis 4.0 software (Bruker Daltonics).
For quantitation of phenolic and flavonoid compounds, calibration curves were prepared using external standards of gallic acid, catechin, 4-hydroxybenzoic acid, chlorogenic acid, epitequina, caffeic acid, vanillic acid, syringic acid, p-coumaric acid, ferulic acid, rutin, ellagic acid, myricetin, quercetin, hesperetin, kaempferol, luteolin, apigenin, pinocembrin, chrysin and galangin, in the concentrations ranging from 0 to $10 \mu \mathrm{g} / \mathrm{ml}$. Phenolic compounds present in the samples were characterized by their UV/Vis $(220-800 \mathrm{~nm})$ retention times relative to external standards and mass spectrum.

Different concentrations of propolis extracts of 1000 and from 100 to $0.09 \mu \mathrm{g} / \mathrm{ml}$ were added in MDBK (Madin-Darby Bovine Kidney) cell monolayers. Cell viability was assessed by daily microscopic observation of the morphological changes of cells and was measured by MTT assay [3-(4,5 dimethylthiazol-2yl)-2, 5-diphenyl$2 \mathrm{H}$-tetrazolato bromine] after $72 \mathrm{~h}$ of incubation (Amoros et al., 1992). Cytotoxicity was expressed as cytotoxic concentration in $90 \%$ (CC90\%), that is, concentration capable of inhibiting $90 \%$ of cell culture compared to untreated cells. The tests were performed in quadruplicate and repeated three times on alternate days.

For in vitro tests, clinical isolates of Sporothrix brasiliensis from cats $(n=8)$ and $\operatorname{dogs}(n=4)$ with sporotrichosis in the cities of Pelotas and Rio Grande/RS, in southern Brazil, were used, as well as a standard strain of human sporotrichosis (n: 1; code: IPEC 16919 - Clinical Research Institute Evandro Chagas, Fiocruz, Rio de Janeiro / RJ, Brazil; FMR 8314 - Facultat of Medicine i Ciencies de la Salut, Reus, Spain). All isolates were previously molecularly identified by the Medical and Molecular Mycology Laboratory, Federal University of São Paulo (São Paulo/SP, Brazil). The total fungal isolates $(n=13)$ were stored in the mycological collection of the Center for Research and Diagnosis in Mycology Veterinary, Federal University of Pelotas (Pelotas/RS, Brazil).

The minimum inhibitory concentrations (MIC) and minimum fungicidal concentrations (MFC) were determined by microdilution technique in broth, according to the guidelines of the Clinical and Laboratory Standards Institute (CLSI, 2008) and adapted to the use of natural products 
(Waller et al., 2015). Fungal inoculum were prepared from young colonies grown on potato dextrose agar for 7 days at $35^{\circ} \mathrm{C}$ and adjusted in a spectrophotometer (Spectrum Co. Instruments, Shanghai, China) in the transmittance of $80-82 \%$ at the wavelength of $530 \mathrm{~nm}$. The suspensions were diluted in RPMI 1640 (Roswell Park Memorial Institute medium, Sigma, Steinhiem, Germany) supplemented with $2 \%$ glucose and MOPS [3- (N-morpholino propanesulfonic acid)] $(1: 50, \mathrm{v} / \mathrm{v})$. In order to obtain the concentrations of propolis from 0.78 to $0.02 \mathrm{mg} / \mathrm{ml}$, serial dilutions were prepared in RPMI-1640 medium supplemented with $2 \%$ glucose and MOPS in microplates of 96 wells. For negative control, $100 \mu 1$ of RMPI-1640 medium supplemented with $2 \%$ glucose and $100 \mu$ l of MOPS were added. For positive control, $100 \mu 1$ of RMPI-1640 medium supplemented with $2 \%$ glucose and $100 \mu$ of MOPS and inoculum were prepared. For the use of itraconazole $\left(\right.$ Sporanox ${ }^{\circledR}$, Janssen-Cilag Pharmaceutical Ltda., Lot TLL 089, São José dos Campos/SP, Brazil), the antifungal was prepared in dimethyl sulfoxide (DMSO), according to the CLSI guidelines. The microplates were incubated at $27^{\circ} \mathrm{C}$ for 72 hours for reading the MIC values. To obtain the values of MFC, $10 \mu$ l of each well with no visible fungal growth was transferred to Petri dishes containing Sabouraud dextrose (Acumedia, Lansing, Michigan, USA) and incubated at $27^{\circ} \mathrm{C}$ for 72 hours in order to visualize fungal growth. All experiments were performed in duplicate and repeated twice.

The variance analysis and comparison of geometric means were performed according to the Kolmogorov-Smirnov test for non-parametric data using the statistical program BioEstat ${ }^{\circledR}$ (version 5.3), and the value $\mathrm{P}<0.05$ considered significant.

\section{RESULTS}

The values obtained for cell toxicity in MDBK cells of the three hydroalcoholic extracts of propolis are expressed through the medium of the tested concentrations (Figure 1). In lower concentrations $(0.097$ to $0.39 \mathrm{mg} / \mathrm{ml})$, all extracts did not exhibit cell toxicity compared to control cell. From the concentration of $0.78 \mathrm{~g} / \mathrm{ml}$, cytotoxicity was observed in brown propolis (PM) and green (PV), whereas for jataí propolis (PJ), the cytotoxicity was observed at $1.57 \mathrm{mg} / \mathrm{ml}$. The increasing order of cytotoxic activity was $\mathrm{PJ}<\mathrm{PV}<\mathrm{PM}$.

By liquid chromatography coupled to mass spectrometry in negative mode (negative ESI), qualitative and quantitative analyses of the extracts are shown in Table 2.

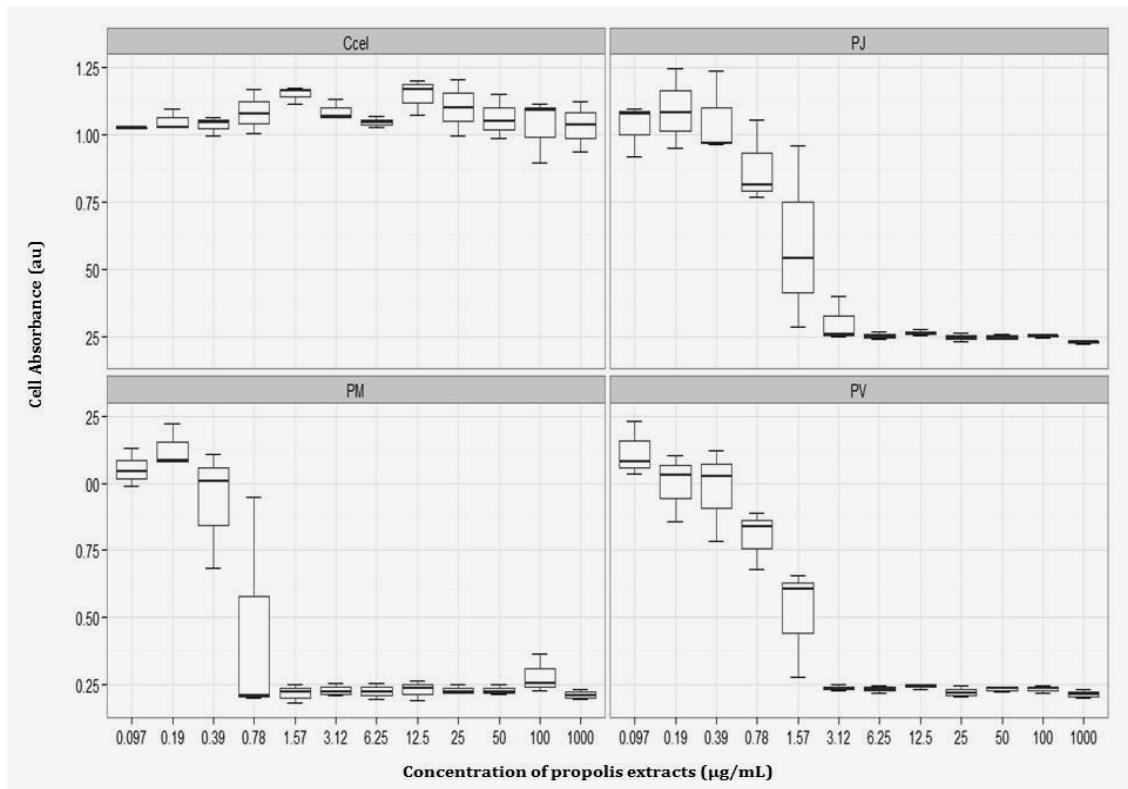

Figura 1. Cytotoxicity of hydroalcoholic extracts of brown propolis (PM), propolis (PV) and jataí bees (PJ) compared to MDBK (CCEL). 
The results of the total phenolic and flavonoid contents of the three propolis varieties produced in southern Brazil are described in Table 1. The total phenolic content determined by the FolinCiocalteu method ranged from $3.93 \mathrm{mg}$ of gallic acid/g for jataí propolis to $41.84 \mathrm{mg} / \mathrm{g}$ for green propolis. In total flavonoid content, the values ranged from $2.5 \mathrm{mg}$ epicatequin/g to jataí propolis to 13 . $46 \mathrm{mg}$ for brown propolis. The results indicated a higher amount of flavonoids in brown propolis, followed by green propolis. Both samples showed higher phenolic content, highlighting green propolis.

Table 1. Total phenolic and total flavonoid contents $\left(\mathrm{mg} \mathrm{g}^{-1}\right)$ identified in the three propolis varieties produced in Southern Brazil (mean \pm SD)

\begin{tabular}{cccc}
\hline Total compounds & Green Propolis & Brown Propolis & Jataí Propolis \\
\hline Phenolic content $^{*}$ & $41.84 \pm 5.39$ & $34.39 \pm 1.91$ & $3.93 \pm 0.54$ \\
Flavonoids content $^{* *}$ & $11.40 \pm 1.49$ & $13.46 \pm 0.74$ & $2.05 \pm 0.53$ \\
\hline
\end{tabular}

* mg of gallic acid per gram of extract; ** mg of epicatechin per gram of extract.

Table 2. Quantitative and qualitative analyses $(\mathrm{mg} / \mathrm{g})$ of hydroalcoholic extracts of Green Propolis, Brown Propolis and Jataí Propolis using liquid chromatography coupled to mass spectrometry in negative mode (negative ESI)

\begin{tabular}{|c|c|c|c|c|c|}
\hline \multirow{2}{*}{ Chemical Compound and respective group } & \multirow{2}{*}{$\begin{array}{c}\mathrm{m} / \mathrm{z} \\
{[\mathrm{M}-\mathrm{H}]^{-}}\end{array}$} & \multirow{2}{*}{$\begin{array}{c}\text { Retention time } \\
\text { (minutes) }\end{array}$} & \multicolumn{3}{|c|}{ Propolis } \\
\hline & & & Green & Brown & Jataí \\
\hline \multicolumn{6}{|l|}{ Phenolic acid } \\
\hline \multicolumn{6}{|l|}{ Hydroxybenzoic acid derivative } \\
\hline Gallic acid & 169.0132 & 5.41 & n.d. & n.d. & n.d. \\
\hline 4-Hydroxybenzoic acid & 137.0233 & 11.17 & + & + & + \\
\hline Syringic acid & 197.0445 & 12.45 & n.d. & + & n.d. \\
\hline Vanillic acid & 167.0339 & 12.12 & n.d. & + & n.d. \\
\hline \multicolumn{6}{|l|}{ Hydroxycinnamic acid derivative } \\
\hline Caffeic acid & 179.0338 & 12.05 & 0.61 & 0.17 & + \\
\hline Chrologenic acid & 353.0867 & 11.27 & 0.96 & 0.36 & 0.26 \\
\hline$p$-Coumaric acid & 163.0390 & 13.67 & 52.09 & 3.39 & 6.6 \\
\hline Ferulic acid & 193.0495 & 14.01 & 0.64 & 0.20 & 0.09 \\
\hline \multicolumn{6}{|l|}{ Hydroxydiphenic acid derivative } \\
\hline Ellagic acid & 300.9978 & 15.21 & + & + & + \\
\hline \multicolumn{6}{|l|}{ Flavonoid } \\
\hline \multicolumn{6}{|l|}{ Flavanone } \\
\hline Catechin & 289.0707 & 10.25 & n.d. & n.d. & n.d. \\
\hline Hesperetin & 301.0707 & 17.33 & + & + & + \\
\hline Pinocembrine & 255.0652 & 19.49 & + & + & + \\
\hline \multicolumn{6}{|l|}{ Flavone } \\
\hline Apigenin & 269.0445 & 18.24 & + & + & + \\
\hline Chrysin & 253.0495 & 20.12 & + & + & + \\
\hline Luteolin & 285.0394 & 17.30 & + & + & + \\
\hline \multicolumn{6}{|l|}{ Flavonol } \\
\hline Epicatechin & 289.0707 & 11.74 & n.d. & n.d. & n.d. \\
\hline Galangin & 269.0444 & 20.53 & + & + & + \\
\hline Kaempferol & 285.0393 & 18.00 & + & + & + \\
\hline Myricetin & 317.0292 & 15.52 & n.d. & n.d. & n.d. \\
\hline Quercetin & 301.0343 & 16.89 & + & + & + \\
\hline Rutin & 609.1450 & 14.64 & 3.71 & 0.81 & 0.65 \\
\hline
\end{tabular}

+ Detectable; n.d. Not detectable; 
Among 21 standard compounds tested, 15 were identified in all propolis extracts, being vanillic acid and syringic acid only identified in brown propolis. Of the compounds detected, chlorogenic acid, caffeic acid, p-coumaric acid, ferulic acid and rutin were quantified in all propolis extracts, except caffeic acid for jataí propolis. P-coumaric acid was the major compound in the three samples of propolis, being highly quantified in green propolis $(52.09 \mathrm{mg} / \mathrm{ml})$, followed by rutin and chlorogenic acid for all extracts.

According to Table 3, green propolis and jatai propolis did not exhibit inhibitory or fungicidal activities at tested concentrations (MIC and MFC greater than $0.78 \mathrm{mg} / \mathrm{ml})$. In turn, all $S$. brasiliensis tested were sensitive to brown propolis in MIC values between 0.78 and $0.09 \mathrm{mg} / \mathrm{ml}$, which varied statistically from other propolis $(\mathrm{P}<0.001)$. The $\mathrm{MIC}_{50}$ for isolates from dogs and cats was $0.19 \mathrm{mg} / \mathrm{ml}$ for both animal species, while the $\mathrm{MIC}_{90}$ was $0.39 \mathrm{mg} / \mathrm{ml}$ and $0.78 \mathrm{mg} / \mathrm{ml}$, respectively, indicating a remarkable inhibitory activity of this bee product. Although MFC values ranged from 0.09 to greater than $0.78 \mathrm{mg} / \mathrm{ml}$ for $S$. brasiliensis from cats, fungicidal activity was not observed in $S$. brasiliensis from dogs, showing weak fungicidal activity of brown propolis in the tested concentrations $\left(\mathrm{MFC}_{90}>0.78 \mathrm{mg} / \mathrm{ml}\right)$.

In relation to the drug of choice in the treatment of sporotrichosis, the MIC values of itraconazole varied from 0.25 to greater than $16 \mu \mathrm{g} / \mathrm{ml}$, where sensitivity of $S$. brasiliensis found in dogs $\left(\mathrm{MIC}_{50}\right.$ of $4 \mu \mathrm{g} / \mathrm{ml}$ and $\mathrm{MIC}_{90}$ of $\left.16 \mu \mathrm{g} / \mathrm{ml}\right)$ was observed. However, this did not occur in $S$. brasiliensis from cats $\left(\mathrm{MIC}_{50,90}>16 \mu \mathrm{g} / \mathrm{ml}\right)$, indicating it in vitro resistance to itraconazole. This antifungal showed no fungicidal activity $\left(\mathrm{MFC}_{50,90}>16 \mu \mathrm{g} / \mathrm{ml}\right)$.

Table 3. Minimal inhibitory concentration (MIC) and minimal fungicidal concentration (MFC) of hydroalcoholic extracts of Green Propolis, Brown Propolis and Jataí Propolis against Sporothrix brasiliensis isolated from animal sporotrichosis

\begin{tabular}{|c|c|c|c|c|c|c|c|c|c|}
\hline \multirow{2}{*}{\multicolumn{2}{|c|}{$\begin{array}{l}\text { Sporothrix brasiliensis } \\
\text { (No. samples) }\end{array}$}} & \multicolumn{2}{|c|}{$\begin{array}{l}\text { Green Propolis } \\
(\mathrm{mg} / \mathrm{ml})\end{array}$} & \multicolumn{2}{|c|}{$\begin{array}{l}\text { Brown Propolis } \\
(\mathrm{mg} / \mathrm{ml})\end{array}$} & \multicolumn{2}{|c|}{$\begin{array}{l}\text { Jataí Propolis } \\
(\mathrm{mg} / \mathrm{ml})\end{array}$} & \multicolumn{2}{|c|}{$\begin{array}{c}\text { Itraconazole } \\
(\mu \mathrm{g} / \mathrm{ml})\end{array}$} \\
\hline & & $\mathrm{MIC}$ & MFC & MIC & MFC & MIC & MFC & MIC & MFC \\
\hline \multirow{3}{*}{ Cats (8) } & Range & $>0.78$ & $>0.78$ & $0.09-0.39$ & $0.09->0.78$ & $>0.78$ & $>0.78$ & $0.25->16$ & $>16$ \\
\hline & $50 \%$ & $>0.78$ & $>0.78$ & 0.19 & $>0.78$ & $>0.78$ & $>0.78$ & $>16$ & $>16$ \\
\hline & $90 \%$ & $>0.78$ & $>0.78$ & 0.39 & $>0.78$ & $>0.78$ & $>0.78$ & $>16$ & $>16$ \\
\hline \multirow{2}{*}{ Dogs (4) } & Range & $>0.78$ & $>0.78$ & $0.19-0.78$ & $>0.78$ & $>0.78$ & $>0.78$ & $0.5->16$ & $16->16$ \\
\hline & $90 \%$ & $>0.78$ & $>0.78$ & 0.78 & $>0.78$ & $>0.78$ & $>0.78$ & 16 & $>16$ \\
\hline \multirow[t]{2}{*}{ IPEC 16919 (1) } & Range & $>0.78$ & $>0.78$ & 0.39 & $>0.78$ & $>0.78$ & $>0.78$ & $>16$ & $>16$ \\
\hline & Range & $>0.78$ & $>0.78$ & $0.09-0.78$ & $0.09->0.78$ & $>0.78$ & $>0.78$ & $0.25->16$ & $16->16$ \\
\hline \multirow{2}{*}{ Overall (13) } & $50 \%$ & $>0.78$ & $>0.78$ & 0.19 & $>0.78$ & $>0.78$ & $>0.78$ & $>16$ & $>16$ \\
\hline & $90 \%$ & $>0.78$ & $>0.78$ & 0.78 & $>0.78$ & $>0.78$ & $>0.78$ & $>16$ & $>16$ \\
\hline
\end{tabular}

\section{DISCUSSION}

Although propolis is considered a natural product and the possible absence of toxicity to humans and animals is reported as one of its qualities (Vynograd et al., 2001), the results showed toxicity in MDBK cells. In different cell cultures, the cytotoxicity has been demonstrated at concentrations of 5\% (Pereira et al., 2002) and $0.0003 \%$ (Sawaya et al., 2004), being described as moderate to highly toxic. These values were different from the present results, because the non-cytotoxic dose of brown and green propolis was $0.097 \mu \mathrm{g} / \mathrm{ml}$, respectively, when compared to the medium of the control cells, whereas for jatai propolis it was $0.39 \mu \mathrm{g} / \mathrm{ml}$.

Jataí propolis was shown to be less toxic $(0.78 \mu \mathrm{g} / \mathrm{ml})$, whereas brown propolis was more toxic $(0.097 \mu \mathrm{g} / \mathrm{ml})$, with these values being equivalent to the higher concentration without morphological alterations in the cells when compared to control cell. This toxicity may be derived from the extraction method, since, according to Paulino et al. (2002), hydroalcoholic extraction allows for removal of a greater amount of bioactive substances in propolis. In greater quantities and variability, 
these substances would have greater toxic action, in addition to significant antifungal action, which was observed in brown propolis.

The identified phenolic and flavonoid compounds in the samples are in accordance with those described in the existing literature. The similarity in the qualitative chemical compositions among the three bee products is in accordance with the findings of Sawaya et al. (2004), which observed that propolis produced by Apis mellifera and Tetragonisca angustula from different regions of Brazil showed similarity in the chemical composition, even to those produced by different bee species. For this observation, the main plant source for the production of jatai propolis should be taken into consideration: Schinus terebinthifolius, popularly known as "red mastic" (Sawaya et al., 2004). Widely distributed in Brazil, this plant also is used as source for the development of other propolis varieties, such as green propolis, which contributes to the similarity in the chemical composition between both samples.

Although green propolis and brown propolis produced by $A$. mellifera have presented chemical similarity, the detection of syringic acid and vanillic acid was observed only in brown propolis. This fact may be due to the geographical region of collection, since this factor may influence in the chemical composition of propolis produced by these bee species (Vynograd et al., 2001). In jataí propolis, the presence of caffeic acid in the composition was not observed, and, in relation to quantitative analysis, this product showed lower values when compared to the other propolis varieties. This fact may be explained by the $T$. angustula species (Bankova et al., 2000), as well as the findings of Pereira et al. (2002), that observed the higher concentration of phenolic acids in propolis produced by A. mellifera in comparison to propolis produced by $T$. angustula.

For the first time, the activity of three Brazilian propolis varieties was studied in contrast to the main etiological agent of sporotrichosis in Brazil. Among the products, brown propolis has shown to be promising, because all $S$. brasiliensis isolates were sensitive, including itraconazoleresistant isolates. These results encourage further studies with this bee product, since it has shown potential applicability as an antifungal product. In addition to brown propolis, other products from bees have been described as promising in the treatment of sporotrichosis, such as red Brazilian propolis and Bulgarian propolis (Salomão et al., 2008) against S. schenckii. These same products were active against others fungal species of interest, such as Candida albicans and Paracoccidioides brasiliensis (Salomão et al., 2008).

Although the other propolis varieties have not shown to be active against $S$. brasiliensis, their antifungal activities were documented. Dermatophyte species of Trichophyton were susceptible to green propolis (Siqueira et al., 2009), as well as yeasts of Candida albicans and C. glabrata to jatai propolis (Campos et al., 2014), demonstrating that different propolis were active against pathogenic fungi of human and veterinary interest.

\section{CONCLUSIONS}

In the present study, the total phenolic and flavonoid contents of three Brazilian propolis varieties were determined, showing similarity to each other in their chemical composition. The presence of compounds with recognized antimicrobial activity were also determined. In the evaluation of cell toxicity, jatai propolis was the least cytotoxic of the studied products. In antifungal activity, brown propolis excelled as the only propolis with anti-Sporothrix brasiliensis activity. This study showed the promising use of brown propolis as an antifungal in the treatment of sporotrichosis caused by Sporothrix brasiliensis. However, further studies should be undertaken in order to understand its efficacy and security. 


\section{REFERENCES}

AGÜERO, M.B.; SVETAZ, L.; BARONI, V. et al. Urban propolis from San Juan province (Argentina): ethnopharmacological uses and antifungal activity against Candida and dermatophytes. Ind. Crops Prod., v.57, p.166173, 2014.

AMOROS, M.; SAUVAGER, F.; GIRRE, L. In vitro antiviral activity of propolis. Apidologie, v.23, p.231-240, 1992.

BANKOVA, V.; DE CASTRO, S.L.; MARCUCCI, M.C. Standardization of propolis: present status and perspectives. Apidologie, v.31, p.3-15, 2000.

BASTOS, E.M.A.F.; GALBIATI, C.; LOUREIRE, M. et al. Indicadores físicoquímicos e atividade antibacteriana de própolis marrom frente à Escherichia coli. Arq. Bras. Med. Vet. Zootec., v.63, p.1255-1259, 2011.

ÇAM, Y.; KOÇ, A.N.; SILICI, S. Treatment of dermatophytosis in young cattle with propolis and Whitfield's ointment. Vet. Rec., v.165, p.5758, 2009.

CAMPOS, J.F.; SANTOS, U.P.; MACORINI, L.F.B. et al. Antimicrobial, antioxidant and cytotoxic activities of propolis from Melipona orbignyi (Hymenoptera, Apidae). Food Chem. Toxicol., v.65, p.374-380, 2014.

CARRADA-BRAVO, T.; OLVERA-MACÍAS, M.L. New observations on the ecology and epidemiology of Sporothrix schenckii and sporotrichosis. Rev. Latinoamer. Patol. Clin., v.60, p.5-24, 2013.

CHAVES, A.R.; CAMPOS, M.P.; BARROS, M.B.L. et al. Treatment abandonment in feline sporotrichosis - study of 147 cases. Zoonoses Public Health, v.60, p.149-153, 2013.

CHUA, E.G.; PAROLIA, A.; AHLAWAT, P. et al. Antifungal effectiveness of various intracanal medicaments against Candida albicans: an exvivo study. BMC Oral Health, v.14, p.53, 2014.

CLSI - Clinical and Laboratory Standards Institute. Reference method for broth dilution antifungal susceptibility testing of filamentous fungi. Publication M38-A2. Approved standard. 3.ed. Wayne, PA: CLSI, 2008. 25p.
JUG, M.; KONCIC, M.Z.; KOSALEC, I. Modulation of antioxidant, chelating and antimicrobial activity of poplar chemo-type propolis by extraction procures. LWT Food Sci. Technol., v.57, p.530-537, 2014

KHOSRAVI, A.R.; SHOKRI, H.; NIKAEIN, D. Yeasts as important agents of onychomycosis: in vitro activity of propolis against yeasts isolated from patients with nail infection. J. Altern. Complement. Med., v.19, p.57-62, 2013.

MADRID, I.M.; MATTEI, A.S.; FERNANDES, C.G. et al. Epidemiological findings and laboratory evaluation of sporotrichosis/a description of 103 cases in cats and dogs in southern Brazil. Mycopathologia, v.173, p.265$273,2012$.

MARIMON, R.; SERENA, C.; GENÉ, J. et al. In vitro antifungal susceptibilities of five species of Sporothrix schenckii. Antimicrobiol. Agents Chemother., v.52, p.732-734, 2008.

ORTEGA, N.S.; CAMPO, N.B.; CABEZASFAJARDO, F.A. Actividad antibacteriana y composición cualitativa de propoleos provenientes de zonas climáticas del Departamento del Cauca. Rev. Biotecnol. Agropecu. Agroind., v.9, p.8-16, 2011.

PAIXÃO, A.G.; GALHARDO, M.C.G.; ALMEIDA-PAES, R. et al. The difficult management of disseminated Sporothrix brasiliensis in a patient with advanced AIDS. AIDS Res. Ther., v.12, p.12-16, 2015.

PAULINO, P.; SCRIMIM, F.M.; RAICHASKI, L.B. et al. Mechanisms involved in the relaxant action of the ethanolic extract of propolis in the guinea-pig trachea in-vitro. J. Pharm. Pharmacol., v.54, p.845-52, 2002.

PEREIRA, A.S.; SEIXAS, F.R.M. S.; AQUINO NETO, F.R. Própolis: 100 anos de pesquisa e suas perspectivas futuras. Quím. Nova, v.25, p.321-326, 2002.

RODRIGUES, A.M.; HOOG, G.S.; CAMARGO, Z.P. Genotyping species of the Sporothrix schenckii complex by PCR-RFLP of calmodulin. Diagn. Microbiol. Infect. Dis. v.78, p.383-387, 2014. 
ROMEO, O.; CRISEO, G. Whats lies beyond genetic diversity in Sporothrix schenckii species complex? New insights into virulence profiles, immunogenicity and protein secretion in $S$. schenckii sensu stricto isolates. Virulence, v.4, p.203-206, 2013.

SALOMÃO, K.; PEREIRA, P.R.S.; CAMPOS, L.C. et al. Brazilian propolis: correlation between chemical composition and antimicrobial activity. Evid. Based Complement. Alternat. Med., v.5, p.317-324, 2008.

SANCHOTENE, K.O.; MADRID, I.M.; KLAFKE, G.B. et al. Sporothrix brasiliensis outbreaks and the rapid emergence of feline sporotrichosis. Mycoses, v.58, p.652-658, 2015.

SAWAYA, A.C.H.F.; TOMAZELA, D.M.; CUNHA I.B.S. et al. Electrospray ionization mass spectrometry fingerprinting of propolis. Analyst, v.129, p.739-744, 2004.

SIMONE-FINSTROM, M.D.; SPIVAK, M. Increased resin collection after parasite challenge: a case of self-medication in honey bees? PLoSOne, v.7, p.e34601, 2012.

SIQUEIRA, A.B.S.; GOMES, B.S.; CAMBUIM, I. et al. Trichophyton species susceptibility to green and red própolis from Brazil. Lett. Appl. Microbiol., v.48, p.90-96, 2009.
SONMEZ, S.; KIRILMAZ, L.; YUCESOY, M. The effect of bee propolis on oral pathogens and human gingival fi broblast. J. Ethnopharmacol., v.102, p.371-376, 2005.

STOPIGLIA, C.D.O.; MAGAGNIN, C.M.; CASTRILLÓN, M.R. et al. Antifungal susceptibility and identification of species of the Sporothrix schenckii complex isolated in Brazil. Med. Mycol., v.52, p.56-64, 2014.

VYNOGRAD, N.; VYNOGRAD, I.; SOSNOWSKI, Z. A comparative multi-centre study of efficacy of propolis, acyclovir and placebo in the treatment of genital herpes (HSV). Phytomedicine, v.7, p.1-6, 2001.

WALLER, S.B.; MADRID, I.M.; SERRA, E.F. et al. In vitro susceptibility of the Sporothrix brasiliensis to aqueous extracts of the green-tea (Camellia sinensis L. Kuntze). Acta Vet. Bras., v.9, p.342-347, 2015.

YIGIT, D.; YIGIT, N.; OZGEN, U. An investigation of the anticandidal activity of some traditional medicinal plants in Turkey. Mycoses, v.52, p.135-140, 2009. 